2015-12-01

\title{
How to Remember: War, Armistice and Memory in post-1918 British fiction
}

Smith, Angela

http://hdl.handle.net/10026.1/5325

10.1177/0047244115599143

Journal of European Studies

Sage

All content in PEARL is protected by copyright law. Author manuscripts are made available in accordance with publisher policies. Please cite only the published version using the details provided on the item record or document. In the absence of an open licence (e.g. Creative Commons), permissions for further reuse of content should be sought from the publisher or author. 
This is an accepted manuscript of an article published by Sage in Journal of European Studies 2015 available at: DOI: 10.1177/0047244115599143

How to Remember: War, Armistice and memory in post-1918 British fiction

\begin{abstract}
Post-1918 literature has played a major part in determining the way the First World War has been remembered in the British national consciousness. The post-war literary boom in the late 1920 s and early 1930 s has shaped many impressions of the war allowing images of the Western front to dominate memory. This article, however, explores alternative ways that post-war literature has commemorated the war, beginning with the Armistice, to track the significance of memory in Britain in the immediate post-war decades. My concern here is the focus on memory in non-war fiction and some memoir, those stories written in the inter-war decades that do not look backwards, but instead deal with the aftermath, By considering the fiction of writers such as Irene Rathbone, Virginia Woolf, Dorothy L. Sayers and Winifred Holtby as they engage with the complex issues surrounding how to remember, I will examine whether these writers, as women, endorsed the culture of disillusionment or offered alternative modes of remembrance.
\end{abstract}

\title{
Keywords
}

Literature, history, culture, nationality, memory 


\section{How to Remember: War, Armistice and memory in post-1918 British fiction}

I am beginning to rub my eyes at the prospect of peace. I think it will require more courage than anything that has gone before. It isn't until one leaves off spinning round that one realizes how giddy one is. One will have to look at long vista again, instead of short ones, and one will at last fully recognize that the dead are not only dead for the duration of the war: (Lady Sylvia Asquith in Smith, 2000: 324)

On the $11^{\text {th }}$ November 1918 the Great War passed into memory. With the signing of the Armistice, the silencing of the guns, it became a part of history rather than a part of the ongoing present. Undoubtedly, as Lady Sylvia Asquith notes, the shock of this transition could have been as troubling as the conflict itself. War, at least, was a familiar; it had been an integral part of people's lives for more than four years. The prospect of peace, a postwar world haunted by the absent dead, was a potentially daunting place. It had been difficult enough to grasp the full implications of the war as it raged, but memory is a notoriously unreliable thing. British society, giddy from fighting and loss, sought to find ways to shape and contain memory. As Gail Braybon has noted, memory has a particular importance in Britain. 'No other country marks Armistice day with same fervor' (Braybon, 2003: 8). In the decades that followed, literature played an important role in the structuring and development of this cultural memory.

Cultural memory is informed by collective memory, a term first coined by Maurice Halbwachs in his 1925 work, On Collective Memory. Collective memory, 
Chris Weedon and Glenn Jordan suggest, 'signifies narratives of past experience constituted by and on behalf of specific groups within which they find meaningful forms of identification that may empower' (Weedon and Jordan, 2012: 143). This builds on Halbwachs's suggestion that individual memory constitutes 'a part of or an aspect of group memory' (Halbwachs, 1992: 53). Multiple group memories intermingle in the creation of collective memory, textual narratives inevitably impacting on this corroboration. Cultural memory is determined by the ways in which collective memory is translated through a society or culture. Marianne Hirsch explains: 'Always mediated, cultural memory is the product of fragmentary personal and collective experiences articulated through technologies and media that shape even as they transmit memory' (Hirsch, 2002:6). Both collective and cultural memory can be located in what Pierre Nora terms lieux de memoire, sites of memory, which, in our culture, are usually manufactured, 'we must deliberately create archives, maintain anniversaries, organize celebrations, pronounce eulogies, and notarize bills because such activities no longer occur naturally' (Nora, 1989: 12). This is particularly pertinent to the formation of memory in the inter-war period as individuals and groups who had survived the war endeavored to find ways to articulate their remembered shared experience, whether through public ritual or through written text. Hirsch suggests, 'What a culture remembers and what it chooses to forget are intricately bound up with issues of power and hegemony' (Hirsch, 2002: 6). Her concern is with the ways in which gender shapes cultural memory and this certainly impacts of the myths of the First World War that dominate in Britain. Much of the fiction of the 1920s and 1930s considered here, predominantly by women, offers alternative ways of remembering, multiple narratives of the longer term impact of the war. 
Samuel Hynes argues, 'By the time the decade of the Thirties began, the myth of the War had been constructed in its essential and persisting form and that construction may be regarded as an act of closure both for the war and for the decades that followed' (Hynes, 1990: 459). While he may be right about the construction of the myth, I would argue that the idea of closure is belied in much of other writing of the period. The flood of war literature produced between the outbreak of the war and the early 1930 s was certainly instrumental in shaping cultural memory. By 1918 the landscapes of the Western Front had already come to embody the war in the public imagination. The popular writings of the trench poets had ensured that the trench experience was the most symbolic one of the war. Janet Watson has argued, 'By the end of the war itself, the trench was already becoming a powerful metaphor' (Watson, 2004: 9). She suggests that this was because it was such a new type of warfare as well as being the most common soldiers' experience. Additionally the powerful writing of the trench poets helped to embed the image in the public imagination. Watson argues that although this was ultimately instrumental in creating the sense of disillusionment that came to shape the war cultural memory in the years that followed, early memory of the war retained the sense of patriotism and community that had dominated society for the duration. But as the actual experience of the war ended, and immediate physical memory began to fade, written representations of war experience became more influential in determining how the war would be remembered. The literature boom of the late 1920s and early 1930 s crystallized this representation. The flood of war novels and memoirs into the publishing market, inspired by the phenomenal success of Erich Maria Remarque's 
international best seller, All Quiet on the Western Front (1929) cemented the ideas of sacrifice and disillusionment that had already taken hold of the popular memory. Watson suggests that although the war memoirs and novels of the late reinforced perceived ideas of the war, this was still a retrospective interpretation. 'Sassoon, though he himself in 1917 made perhaps the most famous protest against the war, tells us that the disillusionment these accounts all articulate is a postwar phenomenon, the product of distance in time and space from wartime experiences' (Watson, 2004: 2).

However, Watson also notes, 'The changing nature of memory, in fact, illuminates different moments in the past' (Watson, 2004:5). While the war books of the inter-war years memorialize the conflict in a particular and powerful way, they were by no means the only books to engage with the legacy of the war. My concern here is the focus on memory in the fiction of the aftermath, those stories written in the intervening decades that do not consciously look backwards, but instead purport to deal with the present and the future. Most of the novels considered here are by women who could not have experienced the war in the same way as their male counterparts, which may impact on the way they help to construct cultural memory. As Rosa Maria Bracco has argued, the war is a thread woven through the fiction of the 1920s and 1930s. Its end and its commemoration, often creep into post-war fictions reminding readers of both that legacy and the continuing presence of the war for many people. British cultural memory of the war is developed in these texts as surely as it is in the war books, but in notably different ways (Bracco, 1993: 3); ways that present alternate stories of war and its legacy, which still resonate in the centenary years emphasizing the ongoing significance of how Britain remembers. 
The end of the war was greeted with mixed feelings. Sylvia Asquith's solemn response, in the epigraph, focuses on loss rather than joy. Celebrations everywhere were, for many, similarly tainted. 'Virginia Woolf's diary entry for Armistice Day captures this ambivalence:

Twentyfive minutes ago the guns went off, announcing peace. A siren hooted on the river. They are hooting still. A few people ran to look out of the windows. The rooks wheeled round, \& were for a moment, the symbolic look of creatures performing some ceremony, partly of thanks-giving, partly of valediction over the grave. A very cloudy day, the smoke toppling over heavily towards the east; \& that too wearing for a moment a look of something floating, waving, drooping. (Woolf in Smith, 2000: 320-1))

Woolf's observations adopt pathetic fallacy to articulate her uncertainty. The hooting sirens are intrusive rather than celebratory. A few people try to look at the spectacle, in sharp contrast to the crowds represented in other accounts. The circling rooks disturbed by the noise embody both the positive and negative aspects of ceremony, but ultimately circle a mass grave. The weather, famously bad on $11^{\text {th }}$ November 1918, again endorses the skepticism. The smoke 'floats' 'waves' and finally 'droops', again echoing both crowds and sentiment. The shadows of death, the spectres of legacy penetrate even this early account. In her later memoir, Testament of Youth, Vera Brittain wrote, 'Already this was a different world from the one that I had known during the four life-long years, a world in which people would be light-hearted and forgetful... and in that brightly lit alien world I should have not part. All those with 
whom I had really been intimate were gone; not one remained to share with me the heights and the depths of my memories' (Brittain, 1978: 462-3). The all-important question of memory, of how to remember was already forming in her mind as the maroons still sounded.

Many fiction accounts of the Armistice echo this question. In 1931, Evadne Price, under the pseudonym Helen Zenna Smith, published a sequel to her extremely success 'women's version' of Remarque's All Quiet on the Western Front. Not so Quiet: Stepdaughters of War told of the wartime adventures of Helen 'Nell' Smith, her growing alienation as a consequence of her war experience culminating with the 'death of her soul' in an air raid on the Western Front. The book, based on the diary of an ambulance driver, tapped into the success of the boom in the literature of disillusionment. Women of the Aftermath picks up Nell's story on $11^{\text {th }}$ November 1918, and finds her living in Wimbledon with her blinded, crippled and bitter veteran husband, still harried by her patriotic parents and in-laws. Nell's reaction to the Armistice is one of the most negative and extreme:

We've won the war!...

The world has gone mad. The entire population, it seems, is pouring in to the streets, hatless and coatless, oblivious of the fine misty rain. People are running up and down or round and round in little aimless circles - shouting, screaming, singing, cursing, gesticulating; hoarse with yelling, most of them the rest drunk with excitement - their brains fogged in the intoxication of the moment, as though with alcohol. Self-consciousness is forgotten in the 
temporary insanity. The world has gone mad. (Helen Zenna Smith [Evadne Price], 1931:.31)

The sources for Price's novels are now lost so it is difficult to verify the authenticity of this view point, particularly as many diaries often ended with the war. But it does to some extent, reflect the pessimism of diarists such as Woolf and Brittain. This condemnatory fictional account fits comfortably into the perceived culture of disillusionment that had grown up around the war in the previous decade. Instead of the reeling rooks of Woolf's personal recollection, here drama is all-important and it is the crowds, the 'entire population', 'hatless and coatless' to emphasize their lack of control, who appear to have forgotten themselves. These celebrations are mindless, overblown and disrespectful to the dead. They are quite simply insane, reflecting the jubilation of the older generation who continue to be blamed for sending the youth of Britain to their destruction. Nell's angry response to the Armistice refuses to countenance anything but despair: '...this isn't a day for champagne and parties; it's a day for mourning. It isn't a day for uniforms and medals; it's a day for sack-cloth and ashes... I mean the thousands of others who are worse than dead.,, Roy, a blinded, useless thing... and me... turned into a nun on my wedding day' (Smith, 1931: 28). Here she rejects the inclination to celebrate, a sentiment that is presented as belonging only to the non-combatant majority. Smith's picture is entirely bleak. Roy shoots himself and Nell, rejected by her family, eventually turns to prostitution, collectively imaging the worst outcomes for war veterans, both male and female, in the post war years. 
However, Women of the Aftermath may simply be reflecting the myth of the war created by developing memory in the 1920s. Janet Watson argues, 'From reading the well-known elite texts alone, one would wonder who, in fact, did any celebrating at all. By examining lesser-known personal writings, however, it seems that a lot of people were jubilant at the end of the war' (Watson, 2004: 293). Adrian Gregory endorses this, arguing 'Despite the fact that the country was in the grip of a lethal influenza epidemic, the Armistice on 11 November 1918 was greeted with joy. The end of the war was far more genuinely popular that its beginning' (Gregory, 2008: 250). For example, VAD Hilda Craven was able to rejoice, 'the great day of all days. ...11.00 the guns went off proclaiming peace at last and we all nearly went mad... London mad with joy and it was grand to see the lights full on again and to hear good-hearted cheers' (Craven in Smith, 2000: 319). For Craven, madness is a positive reaction, reflecting joy and relief. As this and other accounts suggest a great many people did fill the streets of the capital and other cities with little other than celebration on their minds at the news.

As the years passed Armistice Day became an established event in the annual calendar, endorsing Nora's assertion of the need to organize commemorative rituals. But responses to it varied. Charles Carrington recalled:

The first Armistice Day had been a carnival; The Second Armistice Day, after its solemn pause at the Two Minutes' Silence... was a day of festivity again. For some years I was one of a group of friends who met, every Armistice Day, at the Café Royal for no end of a party, until we began to find ourselves out of key with the new age. Imperceptibly, the Feast-Day became a Fast-Day and 
one could hardly go brawling on the Sabbath. The do-gooders captured the Armistice, and the British Legion seemed to make its principal outing a day of mourning. To march to the Cenotaph was too much like attending one's own funeral, and I know many old soldiers who found it increasingly discomforting, year by year. We preferred reunions in private with no pacifist propaganda. (Carrington, 1965: 258)

It is interesting to note that Carrington, an ex-soldier, associates the public face of memory with pacifism here, reflecting the growing sense of disillusionment with the war in the decade following the Armistice. But he also identifies it as propaganda, an official prerogative to interpret memory of the war entirely through loss at the expense of those who had survived. Carrington's collective memory finds its roots in a different social group to Woolf or Brittain. Developing cultural memory presents a picture that is alien to the one of celebration that the anniversary represents to him and his comrades. They advocate a different way of remembering. Adrian Gregory takes issue with the notion that loss was in fact an accurate basis for the primary force of commemoration. He argues in fact only $10 \%$ of the population actually lost a close family member. 'The long-standing assumption that every family "lost someone" explodes in light of this, or at the very least has to be radically redefined' (Gregory, 2009: 253). He goes on to suggest that Carrington's discomfort, as a survivor, was well placed:

Undoubtedly the post-war did see a form of 'fictive community' of loss. But we would do well to realize that in important respects it was fictive in the sense of untrue. Depictions of Britain in the 1920 s as a traumatized society with a 
shattered sense of itself, should be understood for what they are:

constructions to cover up a much more complex social reality of winners and losers, continuities and changes. (Gregory, 2009:257)

As Hirsch asserts, what is remembered corresponds to the primary 'male' myth of experience of the war and the consequent bereavement of the population. The idea of 'winner and losers' is addressed in many fictions of the 1920s and 1930s that incorporate various representations of Armistice Day as they grapple with the importance of memory and remembrance. In her 1932 novel, We that Were Young, Irene Rathbone reflects positively on the moment of the Armistice. 'The night of the $10^{\text {th }}$. The morning of the $11^{\text {th }}$. The world held its breath. Eleven o'clock. Sirens and a crash of bells. The world went mad. The Armistice was signed' (Rathbone, [1932] 1988: 407). Her central protagonist, Joan Seddon, who has carried out a variety of different kinds of war work, while aware of the many dead, is overjoyed by the fact that her brother and fiancé have survived the war. For her it is a moment of relief. However her brother's death from influenza eleven days later, followed by her fiancé being killed in post-war Iraq, (both of which reflect Rathbone's own experience), ensures that in fact she cannot escape bereavement, ultimately changing her response.

We That Were Young is a war book, albeit one that explores war from the marginal gendered position of women's experience. But Irene Rathbone goes on to addresses the veteran's plight. Joan is one of the bereaved, and as such there is no escape from being a part of a collective memory for her, but she shows equal concern for the survivors, like Nell Smith, apparently abandoned by the State. Ten 
years later, as she organizes an Armistice Day meeting in support of the League of Nations, Joan reads of the suicide of an old friend. His explanatory note reads:

Ten years after the Armistice I find that the world is not worth living in, and that I, personally, have failed to make it better. I cannot face another celebration of that day which seemed to many of us such a radiant dawn. Nowhere have responsibilities been shouldered or promises been fulfilled; everywhere is an under-current of despair and shame. I prefer to be with those who died before they knew.' (Rathbone, [1932], 1988: 462)

These sentiments articulate the culture of disillusionment identified by Watson and others. The end of the war represented hope, but society could not deliver. Watson suggests that We That Were Young 'is very much a story of the 1930s, a retrospective view of the impact of the war that was clearer fourteen years after the Armistice than it had been at the time' (Watson, 2004: 240). The ritual of remembrance, Armistice Day, well established by 1928, echoes the ambivalence set up in Woolf's diary entry. Here described ironically as a 'celebration', for Joan it is a double-edged ceremony.

Soon, all over London, would be reigning the two-minutes silence which, whenever she was caught in it out in the streets, roused in her an obscure irritation. For the ceremony was at the same time beautiful, futile and a reproach. It was also a species of let-off. 'Remember for two minutes; you can then forget, and resume.' As though one wanted to remember - in that fashion; as though one wanted to forget. (Rathbone, [1932], 1988: 463) 
For Joan, for Rathbone, the formalized process of British collective remembrance is 'beautiful and futile.' It is a 'species of let-off'. She captures here the complexity of memory of a catastrophic event. As a bereaved woman it is painful to remember and to forget in equal parts. The two minutes silence is so deeply embedded in British culture by 1928 that it is not questioned, but this was problematic for many in these early years owing to different forms of collective memory. The disillusionment of the survivors is Rathbone's primary message in these closing pages of her novel. Joan articulates the particular anguish of her generation, a 'lost generation' illustrating the way in which women's literature played its part in creating this impression.

Can you believe... That we were all young once? ... all our generation - all our brothers and our friends, No other generation ever was so young or ever will be. We were the youth of the world, we were on the crest of life, and we were the war. No one above us counted, and no one below. Youth and war were the same thing - youth and the war were us.... Why just us? The knife cut so close - above and below. (Rathbone, [1932], 1988: 464)

Rathbone echoes the sentiments at the heart of Smith's Women of the Aftermath. She helps to create that mythology of a distinct war generation for whom there can be no salvation with the peace. For them, memory is all they have left in a postwar world, a world in which they cannot settle or thrive. Watson suggests, 'In 1932 Rathbone (through Joan Seddon) was staking a claim for the legitimacy of experience, for membership in a war generation that included both men and women' (Watson, 2004: 245). She is making a case for the expansion of cultural memory to 
allow for alternative narratives to include the role of women civilians and suffering veterans as well as simply soldiers but the trenches were already casting a long shadow. Jessica Meyer has argued for the importance of these alternative narratives, through consideration of the plight of veterans, particularly one particular type of 'loser', those suffering from shell shock, and their impact on the women in their lives. She suggests, 'neurasthenia was a long-term condition for many of the men who suffered from it, a fact which denied them the opportunity of ever fully returning to their families in the roles they expected to play' (Meyer, 2004: 129). Where such relationships are explored in the fictions of the inter-war years, they offer a distinct alternate narrative of how to remember the war.

Dorothy L. Sayers's 1928 novel The Unpleasantness at the Bellona Club, an outing for her famous detective Lord Peter Wimsey, is not a war book, but has a plot built around the rituals of remembrance, hinging on the fact that by the late 1920s it had become firmly established in the national psyche. The novel opens in the eponymous Bellona club on Armistice night as Wimsey arrives for an informal dinner hosted by a Colonel Marchbanks in honour of his dead son. It begins with an encounter between Wimsey, himself a veteran, and former soldier Captain George Fentiman, both of whom suffer from neurasthenia following their war service. The chapter ends with the discovery of the body of Fentiman's elderly uncle, the 'unpleasantness' of the title, which prompts a hysterical outburst from George. '"Take him away!" said Fentiman, "take him away. He's been dead two days! So are you! So am I! We're all dead and we never noticed it!' (Sayers, [1928], 2003: 5). 
Although Fentiman senior is 'ninety, if he's a day,' (Sayers, [1928], 2003: 2) it soon transpires that he is also a murder victim and his nephew one of the suspects. Sayers uses the rituals of remembrance and the importance of memory to shape her detective fiction, which on one level conforms to the formulas of the genre. But the inclusion of characters, scarred by the war in unexpected ways complicates memory and problematises the rituals in ways that echo Joan Seddon's discomfort. As Wimsey investigates it becomes clear that the time of death will be the crucial factor in solving the case. A complex will, the beneficiaries of which are determined by whether or not his elderly sister survives the deceased, ensures that there are many potential suspects. It is the ritual of remembrance itself that enables Wimsey to work out what has actually happened. He ascertains that Fentiman senior was not wearing a poppy when his body was discovered, despite the fact that it was the evening of Armistice Day. Because, in 1928, it is inconceivable that a military man would not be wearing this well-established symbol of remembrance, Wimsey is able to prove that he had, in fact, been murdered on the previous day.

Stacy Gillis has argued:

The Golden Age detective novel is both a place in which the dismembered and bloody body of the battlefield can be neatly reassembled and a space in which such motifs of war as shell shock are renegotiated. Both of these should be understood as mourning strategies, points in a constellation of bereavement attuned to the particular damage to British domestic consciousness by the war. (Gillis, 2007: 185) 
Gillis suggests that although the plots are generally not war related, the recurring bodies in detective fiction of the period tap into the national need to find closure for the war dead. The British decision not to repatriate the bodies of the casualties meant that many of the bereaved struggled to move on. Detective fiction always provides closure; the dead are always vindicated. In this way, novels such as The Unpleasantness at the Bellona Club both assist collective mourning and contribute cultural memory. The detection plot gives a clear indication of the importance of British remembrance a decade after the war. But Sayers does more than that, inviting her readers to engage with the consequences of war for those who have survived and their families.

Adrian Gregory suggests, 'If ex-servicemen retained a place in the popular perception of what 11 November was about, it must be remembered that it was a subordinate place. The civilian bereaved always came first in any clash of interests' (Gregory, 1994: 51). Sayers's whole sequence of Peter Wimsey novels operates to highlight the impact of the war on survivors. Wimsey's war service, though distinguished, has left him with a nervous disposition. 'In 1918 he was blown up and buried in a shell-hole near Caudry, and that left him with a bad nervous breakdown, lasting, on and off, for two years' (Sayers, [1928], 2003: 274). The 1920s saw a growth in literary interest in the psychological effects of the war on veterans. On the one hand it became clear that veterans could suffer from debilitating psychological wounds that left them as unable to work and contribute to society as their physically disabled comrades. On the other, understanding these neurasthenic veterans tapped into the Modernist preoccupation with interior space and inner life, that exploration of the psyche at the heart of much narrative experimentation. Ford Madox Ford's 
Christopher Tietjens, the protagonist of his Parade's End tetralogy, is amongst other things, a neurasthenic veteran. Ford's adoption of a stream of consciousness narrative technique throughout the novel sequence enables him to explore the impact of war on Tietjens from the inside. D. H. Lawrence juxtaposes physical disability with psychological in Lady Chatterley's Lover as the crippled Clifford Chatterley and the emotionally scarred Mellors compete for the attention of Connie. Virginia Woolf's Septimus Warren Smith, who will be discussed later, twinned with her eponymous heroine, Clarrisa Dalloway, emphasizes the feminized nature of the shell-shock victim. Woolfs use of a stream of consciousness narrative allows the reader inside Septimus's mind as he traverses a London as rife with danger as the Western Front that so damaged him. In each of these texts there is an underlying accusation; British society has failed to make adequate provision for these invisible victims of war. They struggle to integrate, they cannot adequately contribute and in some cases, as with Septimus, they cannot survive.

Lord Peter Wimsey, however does survive. The sequence of novels concluded in 1937 with Busman's Honeymoon in which he marries fellow detective Harriet Vane and finally finds a reprieve from his nightmares. But his own condition does make him particularly sympathetic to the position of George Fentiman in The Unpleasantness at the Bellona Club. Fentimen's neurasthenia makes it impossible for him to hold down a job for any length of time, leaving him dependent on the earnings of his wife, Sheila, undermining his position as both an ex-soldier and a man. His response to his own shame is to treat his wife badly putting strain on their relationship and embarrassing Wimsey as he observes their discomfort. Yet despite George's difficult behavior and Sheila's anxiety, Wimsey's sympathetic perspective 
ensures that the reader can begin to empathize with the experience of both characters. The result, as with the other fictions noted here, is to publicize the plight of veterans with invisible disabilities. George Fentimen fits into the narrative framework of commemoration but also ensures that readers cannot forget the ongoing issues of the war. The dead man in this novel is not a First World War veteran. Memory here is concerned with the living in a society where selective memory has come into play, the 'species of let-off' that concerned Irene Rathbone.

For some fictional veterans there is no 'species of let-off. Virginia Woolf's Septimus Warren Smith in her novel Mrs Dalloway (1925) is perhaps one of the best known. Sharon Ouditt suggests, 'the war is ... clearly visible in this novel... as a massive social eruption which continues to interrupt daily life long after the Armistice. (Ouditt 1994: 189). The eponymous Clarissa Dalloway, the middle-aged wife of an MP, travels around a London planning her party, dreaming of her pre-war youth as she anticipates the guests. Her daughter Elizabeth, representing a new, post-war generation, explores a cityscape of potential and liberation. But the London of Septimus remains a terrifying continuation of the Western Front. Septimus is a survivor of the war, an ex-soldier victim of the combined trauma of shell shock, grief at the loss of his officer, Evans, and the consequences of his repressed homoerotic feelings. Despite the company of his wife, Lucrezia, and the urban setting, he cannot escape the legacy of his war experience. Like Fentiman, he is unable to forget in a world where memory is becoming sacred. Septimus's memory does not correspond to the cultural dominant. He is part of a particular collective, but largely invisible group. Thus Woolfs novel becomes a channel for the understanding of memory just as effectively as it embraces many other cultural ideas. Memory, for Septimus, 
concerns disability and exile, the plight of the veteran, intersecting with Clarissa's nostalgic uncertainty. Together their memories, their histories, capture the anxiety of the immediate post-war years.

The violent sound of a car backfiring, that makes Clarissa jump causes Septimus to freeze:

Everything had come to a standstill. The throb of the motor engines sounded like a pulse irregularly drumming through an entire body. The sun became extraordinarily hot because the motor car had stopped outside Mulberry's shop window; old ladies on the tops of omnibuses spread their black parasols; here a green, here a red parasol opened with a little pop... Every one looked at the motor car. Septimus looked. Boys on bicycles sprang off. Traffic accumulated. And there the motor car stood, with blinds drawn and upon the a curious pattern like a tree, Septimus thought, and this gradual drawing together of everything to one centre before his eyes, as if some horror had come almost to the surface and was about to burst into flames terrified him. The world wavered and quivered and threatened to burst into flames. It is I who am blocking the way, he thought. Was he not being looked at and pointed at; was he not weighted there, rooted to the pavement, for a purpose? But for what purpose? (Woolf, [1925],1976: 15)

In this passage Woolf focuses on Septimus's interior life. This not only emphasizes his confusion, but also maps it onto the London Street. Bond Street becomes a trench as surely as the trenches themselves were named after familiar British streets 
and landmarks. The loud explosion, like shellfire returns him to the battle; the throbbing engines are reminiscent of the backdrop of artillery fire; the heat of the sun oppresses. The colours of the flowers and the parasols conjure the poppies on the parapet; the 'popping' of the parasols seem to echo bullets. Boys spring off their bicycles as if searching for cover. The threat of flames in Septimus's head feels real, as if the London Street itself is the battlefield. His fear is tangible in the repetition of the last line. His concern is not how to remember, but how to forget.

For Septimus, as for so many other disabled veterans, the whole of London is an extension of the war. Seated in Regent's Park with his wife he sees a landscape that is ambiguous rather than safe. There is a neurasthenic edge to his attempts to find beauty in the natural world around him, ultimately thwarted by the ghosts of the dead. There is a double edge to everything he sees as he tries to feel at home in the old world. But he cannot. It is haunted and he cannot shake off the fear that the dead will not let him rest. '"For God's sake don't come!'” he begs Evans, but to no avail:

But the branches parted. A man in grey was actually walking towards them. It was Evans! But no mud was on him; no wounds; he was not changed. I must tell the whole world, Septimus cried, raising his hand (as the dead man in the grey suit came nearer), raising his hand like some colossal figure who has lamented the fate of man for ages in the desert alone with his hands pressed to his forehead, furrows of despair on his cheeks, and now sees light on the desert's edge which broadens and strikes the iron-black figure (and Septimus half rose form his chair), and with legions of men prostrate behind him he, the 
giant mourner, receives for one moment on his face the whole - (Woolf, [1925], 1976: 63-4)

The man is not Evans, of course, but Peter Walsh, Clarissa's old admirer also walking around London, fresh from observing uniformed boys at the cenotaph observe a different form of collective memory. Woolfs stream of consciousness effectively captures the manifestations of Septimus's illness by absorbing him into the landscape. In his head he becomes a huge tragic symbol of the grieving process. Memory is overwhelming and inescapable. Meyer suggests that Septimus 'serves as a symbol for the dislocation of the veterans' (Meyer, 2004: 131), highlighting the significance of Woolf's focus on his interior trauma. But his impact on his wife emphasizes the wider importance of shell-shocked veterans in the development of cultural memory. She returns him to himself by asking the time, but it can only be temporary. Meyer states, 'Lucrezia has already lost him, having lost the man she married to the trauma of war' (Meyer, 2004: 131). For Septimus the war continues in a new landscape that is an ironic reflection of the previous one. The effect on him colours the memory of war in those who surround and observe him.

Although a survivor of the war, Septimus is finally defeated by the medical intervention of Sir William Bradshaw, a consultant specializing in neurasthenia, who is determined to treat his shell shock with incarceration. When Bradshaw invades his home, even the domestic space becomes an extension of the battlefield forcing Septimus to flee, as Ouditt puts it, 'over the top, straight on to the bayonet-like railings' (Ouditt 1994: 197). It is a final penetration of the landscape of war into post 
war society, a lingering reminder that the survivors of war could join the numbers of the dead at any time, consigned to memory.

By the 1930s other literatures played a part in developing lieux de memoire, narratives of war memory, exploring the ways in which commemoration had become part of the very fabric of British society. Winifred Holtby's 1936 novel, South Riding is focused around local government politics and personal relationships in a provincial community, based on the one in which she grew up, in the fifteen years following the Armistice. But woven into the tapestry of the novel is the memory of war. It is the event that has moulded the lives of all the protagonists and continues to haunt them despite the passing of years. The ways in which characters remember the war offers a range of perspectives.

Bill Heyer, a small holder and disabled ex-serviceman, recalls the war as a defining point in his life, both in terms of the horror of some of the experiences, but also as the last time he was young, fit and whole. Some elements of his memory conform to the patterns of disillusionment addressed in earlier war memoirs:

...his mind was back in the worst experience of the war, the mud of Passchendaele. His feet groped for the duck-boards through the foetid water. He was carrying rations up to the front-line trenches; the pack ground into his shoulder, the foul ooze seeped through putees and boots. The fear of falling into that filth tormented him. (Holtby, [1936], 1988: 430) 
Holtby plays with familiar tropes here, evoking the corrupt sensuality of the front line, physical hardship enveloped in the rotting landscape to produce psychological terror. Heyer recalls that despite his fear, it was not he, but his friend Scotty, who had drowned into the mud, no doubt fueling his anxiety. 'It was Scotty who had gone down in the mud, and for whose body they had groped in the stench and ordure of the flooded crater. Nothing in all his life had been so horrible as that...' (Holtby, [1936], 1988: 430). The unspeakable horror of the mud overrides even the distress of his 'blighty', and the subsequent loss of his arm leaving him permanently disabled. Yet despite this, Holtby allows him to also articulate the opposing point of view; the war was a time when he was free:

... until he got his blighty he had known good times again. Boxing at the base; the ring in the tent at Amiens; the acid sweaty smell of men crowded together in woolen uniforms, the lights, the referee. The sing-songs in that estaminet near Abbeville. The relief from responsibility, the good fellowship, the pride of manhood and living that grew up there in France under the menace of death. He hungered for it. He knew all the other years must be lifeless and dull compared with those. (Holtby, [1936], 1988: 430-1)

For Heyer, the memory of war is double-edged. Despite the horror and fear of Passchendaele with all its accompanying loss, the war still represents the best years of his life.

For women the memory of war was equally complex. Holtby's female protagonist, Sarah Burton, who accepts the position of Headmistress of the local 
school at the start of the novel, has her own ghosts to deal with. Sarah's fiancé was killed in the war. This coupled with the smaller numbers of available men, has left her a confirmed spinster. She notes, 'I was born to be a spinster, and by god, I'm going to spin' (Holtby, [1936], 1988: 49), indicating her determination to enjoy an alternative to the conventional woman's life as wife and mother. But she is nonetheless haunted by the memory of the war. Attending a concert performed by some of her pupils she is disturbed by the 'Grand Patriotic Finale' in which the participating children take to the stage in the various uniforms of both men's and women's services of the war, singing the patriotic songs of the day. 'Like many women of her generation, she could not listen unmoved to the familiar tunes which circumstances had associated with intolerable memory' (Holtby, [1936], 1988: 70). This intolerable memory is something that has developed for Sarah during the years of peace, and relates not so much to her own experience, as to her understanding of the long-term impact of the war on society. The intolerable is in fact, cultural memory, developed through the rituals of shared remembrance. But for Sarah it appears as lost opportunity rather than commemoration:

With increasing awareness every year she realised what it had meant of horror desperation, anxiety and loss to her generation. She knew that the dead are most needed, not when they are mourned, but in a world robbed of their stabilising presence. Ten million men, she told herself, who should now have been between forty and fifty-five - our scientists, our rulers, our philosophers, the foremen in our workshops, the headmasters in our schools, were mud and dust and the world did ill without them. (Holtby, [1936], 1988: $70-1)$ 
This absence of a generation of men, both literal and symbolic, gives a concrete meaning to the memory that haunts Sarah. While she herself determines to 'spin', and has a successfully developing career in women's education, she is acutely aware that the political structures of both British society and those of Europe have been indelibly marked by the absence of the men who might have populated them. This is more pronounced in the mid 1930s, as a growing undercurrent of fear penetrated society, 'She was haunted by the menace of another war' (Holtby, [1936], 1988: 71). As for Rathbone's Joan Seddon, acts of collective remembrance are painful rather than celebratory, but for different reasons. The children's concert illustrates the level at which ritual commemoration of the war had become embedded in society as the shadow of a further war loomed. The innocence of the child performers, another generation altogether, operates as a tainted echo of the lost innocence of 1914 .

In the closing section of the novel Sarah Burton has a close encounter with death that helps her to re-evaluate the past and look forward. On $6^{\text {th }}$ May 1935, another day of remembrance, the King's Silver Jubilee, she takes a ride in a light aircraft, along with a journalist and photographer, intent on recording the landscape of community celebration below. 'It was a green and white carpet, green pastures, gardens and plantations, white tents, white daisies, and white hawthorn hedges. Long morning shadows striped the living green.' (Holtby, [1936], 1988, p. 481) This is the England that so many fought to protect, preserved and displayed in all its glory. Sarah is still haunted by the recent death of the man she loved, more bereavement, but as the plane falters she is forced to address the idea of her own 
mortality. The crash landing, while it does not injure her, engulfs Sarah in the language of the trenches:

Sarah, who had seen the wall of earth climb, approach, recede, then vault over her head with dazzling ferocity, received a bang above her left eyebrow, and plunged into darkness... to awake with her mouth full of mud, her body sprawling along a narrow pool. (Holtby, [1936], 1988: 486)

This reads like an ironic representation of Bill Heyer's greatest fear, but for Sarah, survival enables her to understand and move on. 'She was bruised and shaken; her head ached, and her left side seemed all stiff and twisted. But she was elated with a senseless exaltation. She had been shaken out of sorrow... Comforted by death, she faced the future.' (Holtby, [1936], 1988: 487) The future, another war, would confuse British cultural memory of the First World War for a time, creating new layers of memory of national suffering to shape rituals of commemoration in Britain. After World War Two Armistice Day became Remembrance Sunday enabling the event to symbolically represent a new 'lost generation' as well as the added collective memories of many other new suffering groups. Over the subsequent decades the nature of the British cultural memory of war became increasingly complex.

The fiction of the inter-war years examined here illustrates the roots of that complexity. The ways in which these writers choose to remember draws upon a range of different collective memories, some of which operate to endorse the myths of disillusionment bound up in the long shadow of the trench experience. And they do this even though the writers are women whose experience of the war has a 
different inflection. But as Hirsch argues we may view 'Women's history as counterhistory that restores forgotten stories to the historical record' (Hirsch, 2002: 7). Here this may be seen as 'countermemory' offering an alternative mechanism for remembrance. Evadne Price and Irene Rathbone, determined to convey the multiple gendered sufferings of their generation, build on the elements of cultural memory inspired by the famous men's memoirs and novels of the war. Others, like Dorothy L. Sayers, Virginia Woolf and Winifred Holtby suggest an alternate focus for memory, one that emphasises the difficulties of survival in a victorious, but bereaved society. These novels ask and attempt to answer the question of how to remember as a part of their wider illustrations of daily life, moving beyond the cultural focus of the trenches.

While rituals of commemoration continue to be questioned, they have been ubiquitous in Britain since January 2014. The undercurrents of collective and cultural memory, so apparent in the fiction of the decades following the war, have burst to the surface, suggesting that in Britain at least, the impact remains of cultural importance in the twenty-first century. The nation is still grappling with the complex question of how to remember. Vera Brittain wrote in the Manchester Guardian on $13^{\text {th }}$ November 1929 of her anxiety that memory would be lost. Her words are echoed in contemporary accounts of the need for commemoration. It seems her fears have proved unfounded.

Time has a deceptive habit of blurring our pain while preserving the glamour of our larger-scale tragedies. Our tears and our anguish fade into oblivion, but the thrill of catastrophic events, the odd brightness of happy moments shining 
through the storm-clouds of disaster, keep the same peculiar vividness that they wore in the yesterday to which they belong. And nature herself conspires with time to cheat our recollections...

By what means shall we recall to life our grief and our terror, in order that posterity may recognize them for what they were? (Brittain, 1985: 209-10)

Bibliography

Berry, Paul and Alan Bishop, (eds.) (1985) Testament of a Generation: The Journalism of Vera Brittain and Winifred Holtby, London: Virago.

Bracco, Rosa Maria, (1993) Merchants of Hope: British Middlebrow Writers and the First World War 1919-1939, Providence and Oxford: Berg.

Braybon, Gail, (Ed.), (2003) Evidence, History and the Great War: Historians and the Impact of 1914-18, New York and Oxford: Berghahn Books.

Brittain, Vera, (1933) Testament of Youth, London: Virago, 1978.

Carrington, Charles, (1965) Soldier from the Wars Returning, London: Hutchinson. Gillis, Stacy, 'Consoling Fictions: Mourning, World War One and Dorothy L. Sayers' in Patricia Rae, (ed.) (2007) Modernism and Mourning, Lewisburg: Bucknell University Press.

Gregory, Adrian, (1994) The Silence of Memory: Armistice Day 1919-1946, Oxford: Berg.

Gregory, Adrian, (2008) The Last Great War: British Society and the First World War, Oxford: Oxford University Press.

Halbwachs, Maurice, (1935) The Collective Memory, (Trans. L. A. Closer) Chicago: Unviesity of Chicago Press, 1992. 
Hirsch, Marianne and Valerie Smith, 'Feminism and Cultural Memory: An Introduction', Signs, Volume 28, Number 3, (Autumn 2002), 1-19.

Holtby, Winifred, (1936) South Riding, London: Virago, 1988.

Hynes, Samuel, (1990) A War Imagined: The First World War and English Culture, London: The Bodley Head Ltd.

Meyer, Jessica, "Not Septimus Now': wives of disabled veterans and cultural memory of the First World War in Britain', Women's History Review, Volume 13, Number 1, 2004, 117-137.

Nora, Pierre, 'Btween Memory and History: Les Lieux de Memoire', Representations, Number 26, (Spring, 1989), 7-24.

Oudit, Sharon, (1994) Fighting Forces, Writing Women: Identity and Ideology in the First World War, London and New York: Routledge.

Rathbone, Irene, (1932) We That Were Young, London: Virago, 1988.

Sayers, Dorothy L. (1928) The Unpleasantness at the Bellona Club, London: New English Library, 2003.

Smith, Angela K., (ed.) (2000) Women's Writing of the First World War: An Anthology, Manchester: Manchester University Press.

Smith, Helen Zenna (Evadne Price), (1931) Women off the Aftermath, London: John Long Ltd.

Watson, Janet, (2004) Fighting Different Wars: Experience, memory, and the First World War in Britain, Cambridge, Cambridge University Press.

Weedon, Chris and Glenn Jordan, (2012) 'Collective Memory: theory and politics', Social Semiotics, 22:2, 143-153, DOI: 10.1080/10350330.21012.664969 Woolf, Virginia, (1925) Mrs Dalloway, London: Grafton, 1976. 
